any of its powers of supervising the conduct, \&c., of midwives to a district council. This should be opposed. There are 139 county and borough councils in England and Wales, and $149 \mathrm{~L}$ urban and rural district councils. What is the good of appointing 1491 "supervising authorities?" Besides, the members, especially of rural district councils are not those who should be entrusted with the chief administrative duties in the Bill. The county councils should themselves act.

6. No penalty is provided if a midwife attend other than "natural labours," or if she give a certificate of stillbirth.

7. The Bill neglects to provide that "any person" may prosecute; Clause 14 puts it upon a district council, this being placed upen the district councils, and this authority will always refuse to prosecute.

8. The Bill excludes Scotland and Ireland, although midwives registered in England can act as midwives in Scotland and Ireland, and no provision is made to supervise them there.

9. No provision is made for the punishment of practitioners or midwives-other than those appointed by the Bill-if they examine or grant documents to intending midwives.

10. Clause 17 provides that the English Branch Council "shall" act for and in the name of the General Medical Council. This is a very dangerous precedent.

11. A clause should be inserted making it penal on both parties if a practitioner employ a midwife as his midwifery assistant.

12. In Clause 18 the term "midwife" should mean a midwifery nurse who undertakes to act only as a nurse to women in childbirth.

If those practitioners who know that their M.P.'s will support a good Bill, and one which will place midwives under close police supervision (as a good number of M.P.'s support a Bill for the latter purpose only) will send the above proposed amendments to them, perhaps good will follow. Practitioners must not think that because the Bill has been read a second time it is certain to pass. Every Government since 1890 has refused to adopt the Bill So if only each practitioner and his friends will oppose the Bill it is not likely to pass. I am, Sirs, yours faitbfully,

Liverpool, March 10th, 1900.

R. R. ReNTOUL

\section{HERNIA OF THE URINARY BLADDER.}

To the Editors of THE LANCET.

Sirs, - In The LanceT of March 3rd Mr. Moynihan, in his third Arris and Gale Lecture, gives an exhaustive account of the above condition. I am surprised to find no reference, in those cases where a cyst has been opened and found to contain fluid resembling urine, to testing the reaction of the escaping fluid with litmus paper. In those cases where the urine has decomposed this method is, of course, useless, but in a large number of cases where the urine is fairly normal it will be found to be acid. This acidity has, so far as I know, only been found in cyst contents in the inguinal region in the case of urine. Therefore, excluding the very remote chance of a hernia of kidney or ureter or an extravasation of urine, the cyst containing the clear yellow fluid must be bladder. I have been in the habit of employing this test for some years and am so impressed by its practical utility that always carry litmus paper in my operation bag. The time saved by this simple test will be appreciated by those surgeons who have been unfortunate enough to accidentally open the bladder when operating for hernia or performing coeliotomy, as the time taken in repairing the bladder is quite long enough without spending a further period in injecting the bladder or in passing sounds.

I am, Sirs, yours faithfully,

Plymouth, March 11th, $1900 . \quad$ C. HAMILTON WhitefoRd.

\section{A NEW MINERAL SPRING AT NAUHEIM: To the Editors of THE LANOET.}

SIRS, - A boring has been in progress here for four months under the dirtetion of Geheime Bergrat Dr. Lepsius, Professor of Geology at the Hessian Grand Ducal Polytechnic College of Darmstadt, and yesterclay a new effervescing thermal brine spring rose from a depth of 207 metres. The present temperature of the water is $89^{\circ} \mathrm{F}$., but will prob. ably after complete development of the spring rise to $95^{\circ}$, the temperature which exists at some depth below the surface. The quantity of carbonic acid gas is to all appearance so abundant that analysis will probably show a percentage of this gas even higher than that of the two similar springs, No. 7 and No. 12, at Nauheim which have up to now been considered the most strongly effervescing thermal springs in Europe. Thanks to this new spring there will be such an abundance of mineral water for bathirg purposes that for a long time to come any demand in this respect will be amply satisfied. Naubeim has thus obtained a valuable and ample increase of its curative resources. I am, Sirs, yours faithfully,

Bad Nauheim, March 8th, $1900 . \quad$ PROFEssor SCHOTT, M.D.

\section{"PULSATING EMPYEMA."}

\section{To the Editors of THE LANCET.}

SIRS,-In an annotation on pulkating empyema on page 719 of THE LANCET of March 10th reference is made to Comby's description of the disease which appeared in 1891 in the Archives de Médecine as the most complete study of the disease. In justice to an Irish writer, the Jate Dr. Robert MacDonnell of this city, I would draw your attention to his monograph, "Contributions to the Diagnosis of Empyema, with Cases" (Hodges and Smith, Dublin, 1844). Nothing has been added to our knowledge of the disease since then and I feel sure that THE LANCET would not willingly or know. ingly deprive a British physician of his laurels to wrongly bestow them on a foreigner.

Dublin, March 12th, 1900 I am, Sirs, yours faithfully, GEORGE FOY.

\section{"THE POSITION OF THE RETIRED ARMY MEDICAL OFFICER." \\ To the Ealitors of THE LANCET.}

SIRS, - The question raised very properly by "Retired on Gratuity" in THE LANCET of March 10th will probably be satisfactorily dealt with by the Departmental Committee of the House of Commons. There is also the larger question of army medical officers, being the only officers in Her Majesty's navy or army resigning on a gratuity, being held "liable to recall to service" up to 55 years of age, after the answer of Mr. St. John Brodrick, then Under-Secretary of State for War, in answer to Colonel Welby's question-viz., "All officers (except subalterns and captains) resigning on a gratuity are liable to recall to service up to 44 years of age." I am, Sirs, yours faithfully, H. G. GABDNER, M.B., C.M. Edin.

Norris-street, S.W., March 13tb, 1900.

\section{CERTAIN DEFICIENCIES IN OUR INFIRMARIES AND ASYLUMS.}

\section{To the Editors of THE LANCET.}

SiRs,-Patients in infirmaries often say: "I like the place well enough; I do not find any fault with either the treatment or food, but I am very much annoyed with my fellow patients-that one over there snores horribly - that one over there coughs terribly - that other one over there raves continually, and that other one talks incessantly, \&c." Now, in these days when people live at high pressure and neurotic diseases predominate over all others, are these annoyances fully considered by the medical attendants of infirmaries? Conld anything be done to mitigate them? Would smaller wards suffice? or would portable partitions (of a material that would not conduct sound readily) between beds be of any use? The above complaints are so commor and must seriously retard the recovery of many patients that they should be seriously considered by the powers that be in infirmaries. Then in asylums patients suffering cnly from a few delusions of ten say: "It was cruel of you to send me here among such a crew ; how can you expect me ever to get well here, with that one singing constantly there, that other one swearing eternally there, and this other one shouting incoherently, incessantly, \&c.?" No doubt superintendents of asylums grade their patients as well as they can; but it is quite impossible for them to do so properly as long as these institutions are district or parochial 